19 Revue d'histoire du XIXe siècle

Société d'histoire de la révolution de 1848 et des

révolutions du XIXe siècle

12 | 1996

L'incendie

\title{
Hommage à Philippe Vigier
}

\section{Francis Démier}

\section{OpenEdition}

\section{Journals}

Electronic version

URL: http://journals.openedition.org/rh19/90

DOl: $10.4000 /$ rh 19.90

ISSN: $1777-5329$

Publisher

La Société de 1848

\section{Printed version}

Date of publication: 1 June 1996

ISSN: 1265-1354

\section{Electronic reference}

Francis Démier, "Hommage à Philippe Vigier », Revue d'histoire du XIXe siècle [Online], 12 | 1996, Online since, connection on 06 October 2020. URL : http://journals.openedition.org/rh19/90 ; DOI : https:// doi.org/10.4000/rh19.90

This text was automatically generated on 6 October 2020.

Tous droits réservés 


\section{Hommage à Philippe Vigier}

\section{Francis Démier}

\section{ABSTRACTS}

No abstract available by now

Pas de résumé disponible actuellement

INDEX

Mots-clés: Hommage, Vigier Philippe 